\title{
E-Government as an Anti Corruption Tool. The Case of Albania
}

\author{
Nikolin Hasani \\ Ph.D student at Faculty of Justice \\ University of Tirana, Albania \\ hasani.nikolin@yahoo.com

\section{Brunilda Beleraj (Ph.D student)} \\ University "Ismail Qemali" Vlore, Albania \\ Faculty of Economy, Department of Business
}

\section{Doi:10.5901/ajis.2013.v2n8p712}

\begin{abstract}
Governments worldwide are faced with the challenge of transformation and the need to reinvent government systems in order to deliver efficient and cost effective services, information and knowledge through information and communication technologies. E-government is the use of information and communication technology (ICT) to promote more efficient and cost-effective government, more convenient government services, greater public access to information, and more government accountability to citizens. One of the benefits of using e-government is the reduce of corruption. Corruption is commonly considered to be one of the most significant impediments to economic development so, for a less corruption society transparent - governance is highly desirable. E-government can ensure more transparency and easy access to information. More transparency means less corruption. This paper outline the role of e-government as an anti corruption tool in Albania.
\end{abstract}

Keywords : e-government, corruption, public services

\section{Introduction}

E-government is not simply a matter of giving government officials computers or automating old practices. Neither the use of computers nor the automation of complex procedures can bring about greater effectiveness in government or promote civic participation. Focusing solely on technological solutions will not change the mentality of bureaucrats who view the citizen as neither a customer of government nor a participant in decision-making. Understood correctly, e-government utilizes technology to accomplish reform by fostering transparency, eliminating distance and other divides, and empowering people to participate in the political processes that affect their lives.

\section{Literature review}

\subsection{E-government definition}

E-government is understood as the use of Information and Communication Technology (ICT) to promote more efficient and cost effective government, facilitate more convenient government services and allow greater public access to information, and make government more accountable to citizens, where as governance is a wider term which covers the state's institutional arrangements, decision making processes, implementation capacity and the relationship between government officials and the public. E-governance is the use of ICT by the government, civil society and political institutions to engage citizens through dialogue and feedback to promote their greater participation in the process of governance of these institutions. Thus, e-government can be viewed as a subset of e-governance, and its focus is largely on improving administrative efficiency and reducing administrative corruption (Bhatnagar Subhash, 2004).

\subsection{Benefits of e-government}

E-Government can also result in huge cost savings to governments and citizens alike, increase transparency and reduce corrupt activities in public service delivery. Previous studies have categorized public service delivery in three groups: 
publishing, interacting, and transacting (Kumar et al. 2007).

It can transform old challenges and create unprecedented possibilities for sustainable economic development, just as it has done for businesses in the industrial world. ICTs offer the potential not just to collect, store, process and diffuse enormous quantities of information at minimal cost, but also to network, interact and communicate across the world (Crede and Mansell, 1998).

Main benefits of E-Government as identified by Ndou(2004) are:

- Cost reduction and efficiency gains (Tapscott, 1996; Amit and Zott, 2001; Malhotra, 2001);

- Quality of service delivery to businesses and customers ;

- Transparency, anticorruption, accountability;

- Increase the capacity of government;

- Network and community creation;

- Improve the quality of decision making;

- Promote use of ICT in other sectors of the society;

○ improving services to citizens;

○ improving the productivity (and efficiency) of government agencies;

- strengthening the legal system and law enforcement;

- promoting priority economic sectors;

○ improving the quality of life for disadvantaged communities;

○ strengthening good governance and broadening public participation.

\subsection{Corruption definition}

\subsubsection{What is corruption?}

The term corruption is used to describe a variety of activities. The students of corruption concentrate on various issues such as bribery, kickbacks, ethics violations, illegal asset accumulation, violations of procurement regulations, political nepotism, cronyism, campaign and party finance violations, money laundering, illegal transactions, freedom of information, public governance, financial accountability and many other issues (see, for example, World Bank 1998; 2000a: 103-109; Transparency International 2001). Although numerous definitions of corruption might be found in the literature, depending on the focus of a particular study, there is convergence on a basic definition that understands corruption as the abuse of public power for private benefit (World Bank 1997; McMoy and Heckel 2001). According to the World Bank (WB), corruption is "the abuse of public office for private gain. Public office is abused for private gain when an official accepts, solicits, or extorts a bribe. It is also abused when private agents actively offer bribes to circumvent public policies and processes for competitive advantage and profit. Public office can also be abused for personal benefit even if no bribery occurs, through patronage and nepotism, the theft of state assets, or the diversion of state revenues." (World Bank 1997: 8-9) This definition is broad enough to encompass all types of corruption one encounters in reality. It also places the public sector at the center of the phenomena of corruption. This report uses this definition of corruption.

\subsubsection{What are the costs of corruption?}

Bribery increases the prices of public works and services, makes the selection of contractors inefficient and wastes those resources that are used in covering illicit activities and obtaining political rents on the basis of manipulated political decisions and protection (della Porta and Vannucci 1999: 10). In addition to these immediate economic costs corruption brings negative long-term consequences mainly in the form of ineffective public administration and the general mistrust of the citizenry in political institutions of a corrupted state. In the words of Donatella della Porta and Alberto Vannucci, "the spread of corruption within the public service introduces elements of inefficiency, where the primary purpose of an operation becomes generation of payoffs. ... the confidence of those in an organization not directly involved in corruption is undermined, leading to generalized inefficiency. At the level of the political system as a whole, the spread of corruption erodes the support and trust of citizens in democracy, in public institutions in general, and in the political class in particular." (ibid.) Hence, corruption does not only hamper the functioning of public administration, but is able to substantially disrupt the democratic institutions of a corrupted state and progressively diminish public support for and trust in political institutions. Last but not least, corrupt members of the political class provide ample opportunities for the networks of organized crime to enter into the political system of a state affected by widespread corruption. Essentially, the 
costs caused by corruption are the reason why corruption should be fought against.

\title{
2.4 Types of corruptions
}

The World Bank in its didactic material from the Youth for Good Governance -distance learning program, defines the main types of corruption as:

\begin{abstract}
"Bribery: An offer of money or favors to influence a public official. Nepotism: Favoritism shown by public officials to relatives or close friends. Fraud: Cheating the government through deceit.

Embezzlement: Stealing money or other government property."
\end{abstract}

It also divides the corruption in two categories:

\begin{abstract}
"Administrative Corruption: Corruption that alters the implementation of policies, such as getting a license even if you don't qualify for it

Political Corruption: Corruption that influences the formulation of laws, regulations, and policies, such as revoking all licenses, and gaining the sole right to operate the beer or gas monopoly."
\end{abstract}

In addition, a classification by magnitude is proposed:

"Grand Corruption: Corruption involving substantial amounts of money and usually high-level officials.

Petty Corruption: Corruption involving smaller sums and typically more junior officials."

\subsection{E-government, transparency, and anti-corruption}

The focus of e-government is shifting gradually from internal efficiency to value-added services for customers and other stakeholders (Melitski, 2003; Pollitt \& Bouckaert, 2000; Stratford \& Stratford, 2000). E-government means the use of technology to enhance access to and delivery of government services in order to benefit citizens, business partners, and employees (Silcock, 2001). E-government has the power to create new modes of public service whereby all public organizations deliver modernized, integrated, and seamless services for citizens. In this shift towards external services, transparency has been increasingly emphasized as a fundamental driver for e-government. E-government initiatives are regarded as a powerful schema for enhancing public transparency (along with internal efficiency and quality service delivery) to the public (Fountain, 2001; Brown, 1999). Northrup and Thorson (2003) cite increased efficiency, increased transparency, and transformation as important reasons for e-government initiatives. In addition, Mulgan (2000) points out e-government transparency efforts in relation to accountability, which has extended its meaning to include transparency initiatives within the work procedures adopted by the government. Compared with earlier forms of e-government infrastructures (Chadwick \& May, 2001), most current e-government websites and systems encompass more interactive features and services in order to restore public trust by providing necessary information and regulations, in addition to quick responses to individual queries (Moon, 2003). By incorporating the agent-principal theory, Smith and Bertozzi (1998) explain the relationship between governments (as agents who work for citizens) and citizens (as principals). Because the government has more control than citizens over the flow of information, members of the government are prone to corruption. In order to narrow the distance between citizens and government, it is necessary to monitor the government's work and provide citizens with information about administrative processes and outcomes regarding, for example, permits or applications. Vishwanath and Kaufmann (1999) share this view and argue that more openness and information sharing enable the public to make informed political decisions, which can improve the accountability of governments.

More information delivered to citizens in a more timely fashion is expected to increase the transparency of government and empower citizens to monitor government performance more closely. Florini (2000) points out that transparency enables citizens to understand a government's accomplishments because the government provides them the necessary information. E-government is, therefore, viewed as a positive channel for enhancing trust in government through government accountability and the empowerment of its citizens (Kauvar, 1998; Demchak et al., 2000). The reality, however, is not so simple. By examining five cases of IT and public section corruption, Heeks (1998) reports that while IT often helps detect and remove corruption, it sometimes has no effect, or creates new opportunities for corruption. IT can lead to an 'upskilling' of corruption and reduced competition for upskilled, corrupt civil servants (Wescott, 2001). 
Since corruption is deeply "rooted in cultural, political, and economic circumstances" (Wescott, 2001), Heeks (1998) suggests 'a more holistic vision,' that includes an information system design and other organizational and environmental factors when implementing a system for corruption control. These concerns about corruption and e-government are translated into practical strategies by some international organizations. UNDP (2004) defines corruption as "the misuse of public power, office, or authority for private benefit." UNDP suggests four strategies to fight corruption: prevention, enforcement, access to information and empowerment, and capacity building (APDIP, 2006). Prevention refers to "reform[ing] administrative procedures, accounting, and procurement practices," enforcement of "institut[ing] proper record-keeping and put[ting] in place effective systems of surveillance and enforcement," access to information and empowerment in order to "promote access to information and enable public and media oversight," and capacity building in order to "strengthen governance systems and processes and provide training." When e-government applications are used to fight corruption, these four strategies need to be integrated in the design and implementation process.

\section{E-government in Albania}

In 2005, the newly elected Albanian government set as a priority the improvement of transparency for governmental services, while in its program for 2009-2013, considering the use of new technologies as a fast track towards development, the government announced the national program "Digital Albania" as one of its major projects, reconfirming its commitment to move forward as a knowledge based economy and the creation of an Information Society.

Public services and efficiency of their distribution have a major effect on economic and social development of a country. Unlike the situation presented in the strategy for Information Technology 2003, today all ministries have their web sites and databases where electronic presented legal acts and regulations, updates on ministry activities, strategic documents, reports different, etc. are published electronically. Work has been conducted GOVNET government network with the support of UNDP and European Commission. Thanks to this project, ministries and departments of the Government of Albania and two public service organizations (in total 18 institutions) are connected through a fiber optic network with high speed. Coming soon is expected to start proceedings for the second phase of this project aimed at reducing costs and improving the network. In this way will be made possible functioning of many government applications.

One of the most important initiatives undertaken by the Ministry of Economy, Trade and Energy is the reform of business registration procedures. This reform, is a significant step in the general government program to improve the business climate in Albania. This is a simple process, the faster and less cost for registering new businesses and registration which is tax administration, social insurance, health insurance and the Labor Inspectorate.

The new law on public procurement provides electronic procurement. E-Procurement supports the automation of tendering activities of different Ministries of the Government and Contractor authorities. This system enables transactions between public institutions and the Albanian national community and international business. Preparation and administration system provides safe, effective and transparent all tender documents and so avoid the delivery of paper documents by providing security throughout the process and avoid corruption and elements. Economic operators may use the services offered by this page to locate procurement competitions and to participate fully in electronic form. Directorate General of Taxation has begun offering for business declaration and payment on-line and also for larger taxpayers. The goal of tax administration is that all payments be made with the statement on-line administrative avoiding burocracy and reducing time.

E-Customs - AYCUDA is a modern system of data processing system during clearance. This process has led to rapid clearance of cargo, has improved control over income and provides accurate and updated information for the trade of goods.

Project implementation started in August 2002 with two main objectives: the establishment of the Albanian version of the program and putting into operation of the program in Tirana and Durres customs. Advantages of the system remain in the automatic processing customs declarations from the moment of registration to the moment of payment, performance unique customs procedures in all branches, the branches connecting customs center, electronic close of transit, processing a large number of data and producing extensive statistical reports. Until today the system has been extended at the Directorate General of Customs and customs of the country focal points enabling that $92 \%$ of transactions be processed through the system.

E-Education - In Albania there are 465000 primary school students and 65000 students of secondary education. There are about 2900 primary schools and about 522 secondary schools. The implementation plan for the development of information technology in schools, include currently 379 operational computer cabinets. The situation as 1 computer for 
45 student, in 2010 aims to be achieved in 1 computer per 25 students.

E-Justice - In this respect are taken some measures for installation of a software structure in intranet and internet for the Ministry of Justice as Bailiff computerization of judicial service, creating a digitized network internal Intranet for all executive system, installing a computer network for the operation of the prison administration

E-Health - In this sector has begun work to establish a management information system for health statistical package from the Ministry of Health in collaboration with the Institute of Insurance. Also with the support of the World Bank have been provided some projects as the creation of an integrated system of national health information

E-Culture - In this field it is aimed to become fund registration and establishment of national museums, cultural assets vice Academy of Sciences, the network connecting branches with a central database of cultural heritage in the National Center of inventory of cultural assets, the creation of a integrated network of cultural tourism guide.

E-Cabinet - It is a new form of electronic communication that allows government-government to draft laws and decisions issued and to be sent later to council of ministers. In this form is made possible online electronic signing after approval of the Draft by the Secretary General and Minister.

E-Questionary - As a result of the adoption requirements in EU, each ministry should meet the required questions. For this, is built an electronic portal that allows throwing the answers from each ministry, communicating with each other and then sending for approval in the council of ministers (AISEG, 2009).

\section{Conclusion and recommendation}

Governments generate huge volumes of information, much of it potentially useful to individuals and businesses. The Internet and other advanced communications technologies can bring this information quickly and more directly to citizens. Enabling them and businesses to readily access government information without having to travel to government offices, stand in long lines or pay bribes.

The employment of ICTs can bring more transparency into public administration and politics. Also, increased transparency will have a tangible effect on corruption only if it is accompanied by measures in two other dimensions of anticorruption struggle - minimizing corruption incentives, i.e. introducing a stable system of remuneration and career prospects for public servants and improving policing, i.e. increasing the probability that corrupt activities will be disclosed. Strengthened control mechanisms and strict penalty provisions should become important components of any successful anticorruption strategy:

E-government has the potential to involve citizens in the governance process by engaging them in interaction with policymakers throughout the policy cycle and at all levels of government. Strengthening civic engagement contributes to building public trust in government. Interactive e-government involves two-way communications, starting with basic functions like email contact information for government officials or feedback forms that allow users to submit comments on legislative or policy proposals.

\section{References}

AISEG. (2009). Report of E-Government Progress in Albania. Agency of Information Society and Electronic Government.

Ferro, E., Benavidaes, L., Taliberti, F., Domene, J. Government as a Way to Reduce Corruption.(online publication).

Hoxha, D., Hakrama, I.. Asilakan, O. A Comparison of E-Government Progress in Turkey And Albania.

InfoDev and The Center for Democracy \& Technology, November2002. The E-government handbook for developing countries.

Kim a, Hyun Jeong Kim b, Heejin Lee . (2009). An institutional analysis of an e-government system for anti-corruption: The case of OPEN. Seongcheol. Government Information Quarterly 26 (2009) 42-50

Monga, A. (2008). E-government in India: Opportunities and challenges, JOAAG, Vol. 3. No. 2

Nkwe N. (2012). E-Government: Challenges and Opportunities in Botswana. International Journal of Humanities and Social Science Vol. 2 No. 17; September 2012.

Ondrej Cisar. (2002). Strategies for Using Information Technologies for Curbing Public-Sector Corruption: The Case of the Czech Republic (CR)1. Final Research Report 2, Released in March 2003. 